\title{
The use of water spinach (Ipomoea aquatica) in domestic wastewater treatment
}

\author{
Thinh V. D. Nguyen*, Huong N. T. Huynh, Mai N. H. Nguyen, \& Thao V. Ngo \\ Department of Environmental Sciences, Nong Lam University, Ho Chi Minh City, Vietnam
}

ARTICLE INFO
Research paper
Received: March 23, 2018
Revised: April 27, 2018
Accepted: May 05, 2018
Keywords
Domestic wastewater
Household
Hydroponics
Wastewater treatment
Water spinach
*Corresponding author
Nguyen Vu Duc Thinh
Email: ducthinh.env@gmail.com

ABSTRACT

The main objective of this study was to examine the efficacy and capacity of using hydroponic systems in municipal pollutant removal at household scale. Three pilot scaled hydroponic systems [dimension for each system: $4.5 \mathrm{~m}(\mathrm{~L}) \times \mathrm{x} \Phi 114 \mathrm{~mm}$ ] were installed to investigate the optimal age of vegetable, planting density and retention time for household wastewater treatment, respectively. Water spinach (Ipomoea aquatica) planted in 27 plastic cups throughout 4.5-m-length and 114mm-diameter uPVC pipes filled with wastewater was employed as the treating agent of pollutants. The averaged influent contained proximately $32.5 \mathrm{mg} / \mathrm{L}$ suspended solids (SS), $76.0 \mathrm{mg} / \mathrm{L}$ biological oxygen demand $\left(\mathrm{BOD}_{5}\right), 220.5 \mathrm{mg} / \mathrm{L}$ chemical oxygen demand (COD), 26 $\mathrm{mg} / \mathrm{L} \mathrm{NH}_{4}^{+}, 5.0 \mathrm{mg} / \mathrm{L} \mathrm{NO}_{3}^{-}$, and $8.5 \mathrm{mg} / \mathrm{L} \mathrm{PO}_{4}^{3-}$ at $\mathrm{pH}$ 7.3. Results showed that a designed system consisting of 10 plants of 15-day-old water spinach pre-planted in baked clay in each cup was capable of treating $30 \mathrm{~L}$ of domestic wastewater meeting the current municipal wastewater discharge standards in Vietnam (column A standards of QCVN 14:2008/BTNMT) after 4 days of wastewater retention time. If operated under conditions of the above parameters, the pilot-plant hydroponic system can achieve the removal of $65 \% \mathrm{SS}, 82 \% \mathrm{BOD}_{5}, 74 \%$ COD, $90 \% \mathrm{NH}_{4}^{+}, 30 \% \mathrm{NO}_{3}^{-}$and $86 \% \mathrm{PO}_{4}^{3-}$. The result of this study has provided an applicable domestic wastewater treatment system ecofriendly and suitable for small and medium household areas.

Cited as: Nguyen, T. V. D., Huynh, H. N. T., Nguyen, M. N. H., \& Ngo, T. V. (2018). The use of water spinach (Ipomoea aquatica) in domestic wastewater treatment. The Journal of Agriculture and Development 17(3), 49-54.

\section{Introduction}

The proportion of domestic wastewater treated is at low levels, and raw wastewater is usually discharged directly to environment in urban areas of Vietnam (MONRE, 2016). Currently, 37 collective wastewater treatment plants have been in operation in urban centers of grade III or higher cities (MONRE, 2016). Wastewater drainage systems, however, have not been completed, causing difficulties in collecting and leading wastewater to treatment plants (MONRE, 2016). Hence, a domestic wastewater treatment plant at household scale is necessary to reduce pollutant loads to environment.

Domestic wastewater can be treated in different ways: mechanically, chemically or biologically
(Luong, 2011; Hoang \& Tran, 2014). Among biological treatments, the hydroponic system is a potential way for wastewater treatment at household scale because it is easy to establish and requires small space and harvested vegetable can be used as food (VEA, 2010). Hydroponic crops can be almost any type of plants such as vegetables, fruits, flowers, garden trees, herbs, ivy, and perennial that crops are harvested after a short planting period (Lem et al., 1990). It is easy to control various environment parameters as nutrients, $\mathrm{pH}$, temperature, oxygen, etc. (Lem et al., 1990). Wastewater would be used instead of chemical fertilizers for growing vegetables. However, hydroponics has disadvantages such as higher initial costs than planting in soil and diseases could spread to the other plants root easily and are dif- 
ficult to control in the case of planting with recirculation systems (Lem et al., 1990).

Ipomoea aquatica, or water spinach, is a herbaceous perennial trailing vine (Patnaik, 1976). It has hollow stems that grow floating or prostrate (Patnaik, 1976). The roots from the nodes penetrate the soil or mud, and the leaves are simple and alternate (Patnaik, 1976). This plant species grows well as a crop in regions where the mean temperature is above $25^{\circ} \mathrm{C}$ (Patnaik, 1976). Hence, hydroponics in Vietnam is a conducive environment for water spinach to flourish.

Previous studies have demonstrated that planting Ipomoea aquatica in fishponds can efficiently remove nutrients and improve water quality $(\mathrm{Li} \&$ Li, 2009; Dai et al., 2012). Accordingly, the current study expected that water spinach could use the nutrients in domestic wastewater for growing and reducing water pollutant loads. Pilot hydroponic systems with water spinach were established to examine the removal percentages of municipal pollutants in wastewater from an apartment. Moreover, the optimal age of water spinach, planting density and retention time were also determined for household guidelines.

\section{Materials and Methods}

\subsection{Domestic wastewater characteristics}

Domestic wastewater was collected from collecting tank of Sunview Apartment, Cay Keo Street, Thu Duc District, HCMC, Vietnam in the morning from January to June 2017 according to TCVN 6663-1:2011 and ISO 5667-1:2006. The wastewater parameters included: water temperature $29^{\circ} \mathrm{C}, \mathrm{pH} 7.3$, SS $32.5 \pm 1.5 \mathrm{mg} / \mathrm{L}$, $\mathrm{BOD}_{5} 76.0 \pm 8.0 \mathrm{mg} / \mathrm{L}, \mathrm{COD} 220.5 \pm 25.5 \mathrm{mg} / \mathrm{L}$, $\mathrm{NH}_{4}^{+}-\mathrm{N} 26.0 \pm 4.0 \mathrm{mg} / \mathrm{L}, \mathrm{NO}_{3}^{-}-\mathrm{N} 5.0 \pm 1.0$ $\mathrm{mg} / \mathrm{L}$, and $\mathrm{PO}_{4}^{3-} 8.5 \pm 1.5 \mathrm{mg} / \mathrm{L}$ and $\operatorname{did}$ not vary much throughout the experiments. Wastewater was pre-filtered through a kitchen sieve to remove large particles, contained in 30-L plastic buckets and transferred to Environmental Technology Laboratory of Faculty of Environment and Natural Resources, Nong Lam University. The wastewater was then analyzed and employed for the experiments immediately.

\subsection{Conditions of water spinach}

Prior to the experimetns, water spinach was grown hydroponically in baked clay at Institute of Biotechnology and Environment (IBE), Nong Lam University. Water spinach seeds were provided by Phu Nong Seeds Company.

\subsection{Experiments}

\subsubsection{Hydroponic systems}

Three pilot scaled experiments consisting hydroponic systems [dimension for each system: 4.5 $m(L)$ x $\Phi 114 \mathrm{~mm}$ ] were installed with water spinach to investigate the optimal age of vegetable, planting density and hydraulic retention time (HRT) for household wastewater treatment, respectively (Figure 1). Water spinach (Ipomoea aquatica) planted in 27 plastic cups throughout 4.5-m-length and 114-mm-diameter uPVC pipes filled with wastewater was employed as the treating agent of pollutants. A similar designed pipe without water spinach was used to make the control.
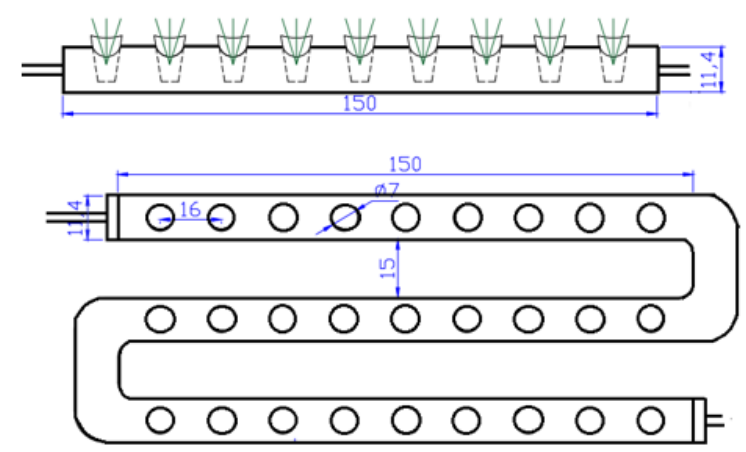

Figure 1. Hydroponic pilot (sizes in $\mathrm{cm}$ ).

The pre-experiments were executed to choose ranges of vegetables' optimal age $(10,15$ and 20 days old), optimal planting density (5, 10 and 15 plants per cup) and optimal retention time (2, 4 and 6 days).

\subsubsection{Determination of the optimal age of veg- etables}

After 10, 15, and 20 days pre-planted in baked clay at IBE, water spinach was transferred to three hydroponic systems, respectively in 27 plastic cups. Each cup contained 10 plants. The control system was made without vegetables. Thirty liters of domestic wastewater were added to each hydroponic systems with HRT $=4$ days. Treated wastewater was collected after HRT to analyze 
$\mathrm{SS}, \mathrm{BOD}_{5}, \mathrm{COD}, \mathrm{NH}_{4}^{-}, \mathrm{NO}_{3}^{-}$, and $\mathrm{PO}_{4}^{3-}$ concentrations remaining.

\subsubsection{Determination of the optimal planting density}

Fifteen-day-old water spinach was planted in 27 plastic cups with 3 different densities of 5,10 and 15 plants per cup throughout the pipes, respectively. The control system was made without vegetables. Thirty liters of domestic wastewater was added to each hydroponic systems with HRT $=4$ days. Treated wastewater was collected after HRT to determine $\mathrm{SS}, \mathrm{BOD}_{5}, \mathrm{COD}, \mathrm{NH}_{4}^{-}, \mathrm{NO}_{3}^{-}$, and $\mathrm{PO}_{4}^{3-}$ concentration residues.

\subsubsection{Investigate the optimal retention time}

Thirty liters of domestic wastewater was added to each hydroponic systems. Fifteen-day-old water spinach was removed from baked clay and put in 27 lastic cups with the density of 10 plants/cup. There were 3 hydroponic systems with 3 different HRTs of 2, 4, and 6 days, respectively. A control system was made without vegetables. Treated wastewater was collected after HRT to analyze SS, $\mathrm{BOD}_{5}, \mathrm{COD}, \mathrm{NH}_{4}^{-}, \mathrm{NO}_{3}^{-}$, and $\mathrm{PO}_{4}^{3-}$ concentrations remaining.

\subsection{Water analysis}

The concentrations of $\mathrm{SS}, \mathrm{BOD}_{5}, \mathrm{COD}, \mathrm{NH}_{4}^{-}$, $\mathrm{NO}_{3}^{-}$, and $\mathrm{PO}_{4}^{3-}$ and $\mathrm{pH}$ of the wastewater out of the hydroponic systems were checked after hydraulic retention time. The water sample was collected stochastically from three locations of each hydroponic system from 8 AM to 9 AM with 100 $\mathrm{mL}$ per model.

Chemical oxygen demand was analyzed according to SMEWW 5220 D (2012). BOD 5 was analyzed according to TCVN 6001-1:2008 and ISO $5815-1: 2003 . \mathrm{NH}_{4}^{-}(\mathrm{LoD}=0.2 \mathrm{mg} / \mathrm{L}, \mathrm{LoQ}=0.5$ $\mathrm{mg} / \mathrm{L}), \mathrm{NO}_{3}^{-}(\mathrm{LoD}=4 \mathrm{mg} / \mathrm{L}, \mathrm{LoQ}=10 \mathrm{mg} / \mathrm{L})$ and $\mathrm{PO}_{4}^{3-}(\mathrm{LoD}=0.04 \mathrm{mg} / \mathrm{L}, \mathrm{LoQ}=0.1 \mathrm{mg} / \mathrm{L})$ concentrations were determined by Sera Test Kits (Germany). In addition, the samples have concentrations of $\mathrm{NO}_{3}^{-}$less than $20 \mathrm{mg} / \mathrm{L}$ were determined by Tropic Marin Test Kits (Germany) with $\mathrm{LoD}=0.5 \mathrm{mg} / \mathrm{L}$ and $\mathrm{LoQ}=1.5 \mathrm{mg} / \mathrm{L} . \mathrm{pH}$ was measured by LAQUAtwin portable $\mathrm{pH}$ meter (HORIBA Scientific, Japan). Temperature was measured by mercury thermometer. Each measurement was made 3 times.

\section{Results}

\subsection{Optimal age of water spinach}

After 4 days, SS, $\mathrm{BOD}_{5}, \mathrm{COD}, \mathrm{NH}_{4}^{-}, \mathrm{NO}_{3}^{-}$, and $\mathrm{PO}_{4}^{3-}$ concentrations of wastewater in the hydroponic systems containing 10,15 , and $20-$ day-old water spinach were $13.0 \pm 1.5,15.0 \pm$ $2.0,61.0 \pm 5.0,4.0 \pm 1.0,3.0 \pm 0.5$ and $2.0 \pm 0.5$ $\mathrm{mg} / \mathrm{L} ; 11.8 \pm 1.3,13.5 \pm 2.5,57.5 \pm 5.5,2.5 \pm$ $0.5,3.5 \pm 0.5$ and $1.2 \pm 0.2 \mathrm{mg} / \mathrm{L}$; and $16.0 \pm 1.0$, $15.5 \pm 2.0,67.5 \pm 6.5,3.5 \pm 0.5,4.0 \pm 1.0$ and $2.5 \pm 0.5 \mathrm{mg} / \mathrm{L}$, respectively (Figure 2 ). The $\mathrm{pH}$ values ranged from 7.9 to 8.1 in the three systems. As a result, the efficiency of the system with 15day-old water spinach was greater than that of the other systems. Therefore, 15-day-old water spinach was employed for the next experiments.

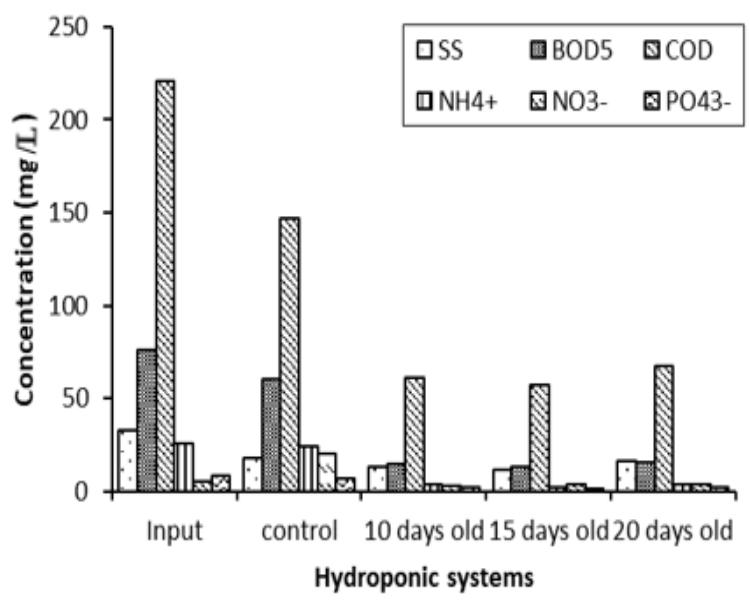

Figure 2. Treated wastewater parameters in hydroponics with different initial ages of water spinach.

\subsection{Optimal planting density}

After 4 days, treated $\mathrm{SS}, \mathrm{BOD}_{5}, \mathrm{COD}, \mathrm{NH}_{4}^{-}$, $\mathrm{NO}_{3}^{-}$, and $\mathrm{PO}_{4}^{3-}$ values of hydroponic systems with 5 plants/cup, 10 plants/cup, and 15 plants/cup were $15.0 \pm 1.5,16.0 \pm 2.0,68.0 \pm$ $7.0,3.0 \pm 0.5,4.0 \pm 0.5$ and $1.5 \pm 0.5 \mathrm{mg} / \mathrm{L}$; $11.0 \pm 1.0,14.0 \pm 2.0,55.0 \pm 5.0,2.5 \pm 0.5,3.0$ \pm 1.0 and $1.2 \pm 0.2 \mathrm{mg} / \mathrm{L} ; 10.0 \pm 1.0,14.0 \pm$ $2.0,57.5 \pm 5.5,2.5 \pm 0.5,3.5 \pm 1.0$ and $1.4 \pm$ $0.2 \mathrm{mg} / \mathrm{L}$, respectively (Figure 3 ). The $\mathrm{pH}$ values ranged from 7.5 to 8.0. Consequently, the optimal density was 10 plants each cup and used in the last experiment. 


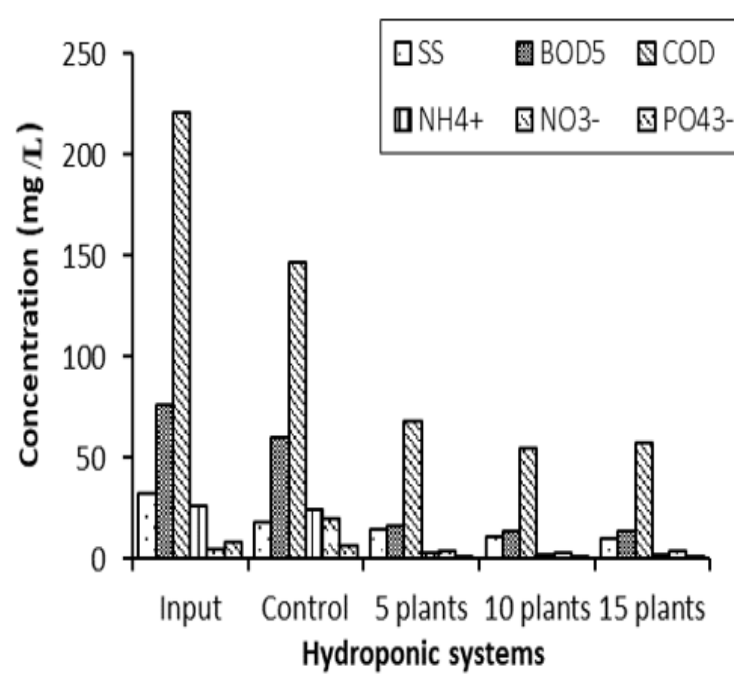

Figure 3. Treated wastewater parameters in hydroponics with different planting densities.

\subsection{Optimal retention time}

After $\mathrm{HRT}=2$ days, $\mathrm{SS}, \mathrm{BOD}_{5}, \mathrm{COD}, \mathrm{NH}_{4}^{-}$, $\mathrm{NO}_{3}^{-}$, and $\mathrm{PO}_{4}^{3-}$ concentrations of wastewater in the experimental hydroponic system were $19.5 \pm$ $1.5,53.0 \pm 6.0,97.0 \pm 15.0,3.0 \pm 0.5,4.0 \pm 1.0 \&$ $2.0 \pm 0.5 \mathrm{mg} / \mathrm{L}$, respectively (Figure $4 \mathrm{a}$ ) and $\mathrm{pH}$ was $7.5 \pm 0.1$ while those of the control system were $24.0 \pm 1.0,68.0 \pm 8.0,160.0 \pm 20.0,24.0 \pm$ $4.0,5.0 \pm 1.0$ and $7.5 \pm 0.5 \mathrm{mg} / \mathrm{L}$, respectively (Figure $4 \mathrm{~b}$ ) and $\mathrm{pH}$ was $7.1 \pm 0.2$. After $\mathrm{HRT}=$ 4 days, $\mathrm{SS}, \mathrm{BOD}_{5}, \mathrm{COD}, \mathrm{NH}_{4}^{-}, \mathrm{NO}_{3}^{-}$, and $\mathrm{PO}_{4}^{3-}$ concentrations of wastewater in the experimental hydroponic system were $11.5 \pm 1.5,13.5 \pm 5.5$, $57.0 \pm 8.0,2.5 \pm 0.5,3.5 \pm 0.5$ and $1.2 \pm 0.3$ $\mathrm{mg} / \mathrm{L}$ respectively (Figure $4 \mathrm{a}$ ) and $\mathrm{pH}$ was $7.8 \pm$ 0.1 while those of the control system were 18.0 $\pm 1.5,60.0 \pm 6.0,146.5 \pm 18.0,24.0 \pm 4.0,20.0$ \pm 2.0 and $7.0 \pm 0.5 \mathrm{mg} / \mathrm{L}$ respectively (Figure $4 \mathrm{~b})$ and $\mathrm{pH}$ was $6.8 \pm 0.1$. These parameters met the current municipal wastewater discharge standards in Vietnam (column A standards of QCVN 14:2008/BTNMT).

After $\mathrm{HRT}=6$ days, $\mathrm{SS}, \mathrm{BOD}_{5}, \mathrm{COD}, \mathrm{NH}_{4}^{-}$, $\mathrm{NO}_{3}^{-}$, and $\mathrm{PO}_{4}^{3-}$ concentrations of wastewater in the experimental hydroponic system were $3.5 \pm$ $0.5,6.0 \pm 1.0,36.0 \pm 7.0,2.5 \pm 0.5,3.0 \pm 0.5$ and $1.2 \pm 0.5 \mathrm{mg} / \mathrm{L}$ respectively (Figure $4 \mathrm{a}$ ) and $\mathrm{pH}$ was $8.1 \pm 0.1$ while those of the control system were $7.0 \pm 1.0,52.0 \pm 6.0,112.0 \pm 15.0,22.0 \pm$ $4.0,25.0 \pm 3.0$ and $7.0 \pm 1.0 \mathrm{mg} / \mathrm{L}$ respectively (Figure $4 \mathrm{~b}$ ) and $\mathrm{pH}$ was $6.5 \pm 0.1$.

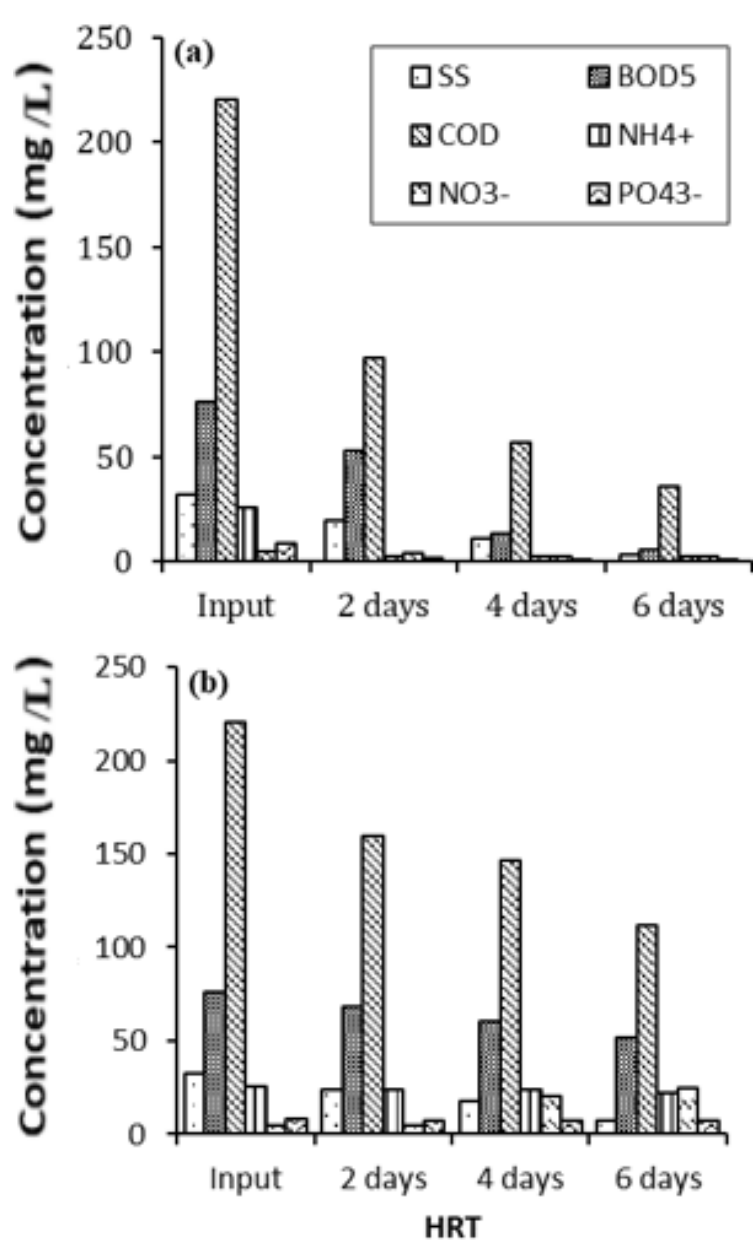

Figure 4. Treated wastewater parameters in (a) hydroponics with different HRTs and (b) the control system.

\section{Discussion}

\subsection{Hydroponics with water spinach}

In general, a hydroponic system consisting of 10 plants of 15-day-old water spinach pre-planted in baked clay in each cup could process $30 \mathrm{~L}$ of domestic wastewater to meet the current municipal wastewater discharge standards in Vietnam (column A standards of QCVN 14:2008/BTNMT) at a HRT of 4 days.

\subsection{1. $\mathrm{pH}$}

$\mathrm{pH}$ of the wastewater out of the hydroponic systems increased slightly from 7.3 to over 7.5 in all experiments. That was because the water spinach in the hydroponic systems absorbed 
$\mathrm{CO} 2$ for photosynthesis, so the $\mathrm{pH}$ of water was increased. $\mathrm{CO} 2$ in the water reacts with water to produce $\mathrm{H}+$ and bicarbonate to decrease $\mathrm{pH}$ of water according to the mechanism: : $\mathrm{CO}_{2}+$ $\mathrm{H}_{2} \mathrm{O} \leftrightarrows \mathrm{H}_{2} \mathrm{CO}_{3} \leftrightarrows \mathrm{H}^{+}+\mathrm{HCO}_{3}^{-}$(Kanabkaew \& Puetpaiboon, 2004). Because $\mathrm{CO}_{2}$ for photosynthesis of aquatic plants is absorbed faster than the amount of $\mathrm{CO}_{2}$ generated from the respiratory process of the quatic plants, plants must take $\mathrm{CO}_{2}$ from the metabolism of $\mathrm{HCO}_{3}^{-}\left(2 \mathrm{HCO}_{3}^{-} \rightarrow\right.$ $\mathrm{CO}_{2}+\mathrm{CO}_{3}^{2-}+\mathrm{H}_{2} \mathrm{O}$ ) (Kanabkaew \& Puetpaiboon, 2004). Therefore, the $\mathrm{pH}$ of water increases.

\subsubsection{SS removal}

The SS concentration decreased from $32.5 \pm$ $1.5 \mathrm{mg} / \mathrm{L}$ to $11.8 \pm 1.3 \mathrm{mg} / \mathrm{L}$ (Figure $4 \mathrm{a}$ ), which means $65 \%$ of SS was removed from the wastewater. The removal of SS may be due to sedimentation or/and breakdown of microorganisms and plants.

\subsection{3. $\mathrm{COD}$ and $\mathrm{BOD}_{5}$ removal}

Previous research has show that COD and BOD5 can be assimilated by plants (Vymazal \& Kropfelova, 2009). The microbes around the roots can also contribute to the purification. The flourishing roots can provide a comfortable environment for microbes. Thus, the organic matter can be removed effectively. The concentrations of $\mathrm{COD}$ and $\mathrm{BOD}_{5}$ decreased from $220.5 \pm 25.5$ $\mathrm{mg} / \mathrm{L}$ to $57.5 \pm 5.5 \mathrm{mg} / \mathrm{L}$ and from $76.0 \pm 8.0$ $\mathrm{mg} / \mathrm{L}$ to $13.5 \pm 2.5 \mathrm{mg} / \mathrm{L}$, respectively (Figure $4 \mathrm{a}) .74 \%$ of the COD and $82 \%$ of the $\mathrm{BOD}_{5}$ were removed from the wastewater. The efficiency of removal at different HRTs was quite difference. The efficiency of short HRT (2 days) was lower than that of middle HRT (4 days) (Figure 4). This could be because the plants needed a period of time to adapt to the new environment. When the roots grew flourishing, the plants could purify the water by assimilation of organic matters and nutrients.

\subsubsection{Nitrogen removal}

The concentrations of $\mathrm{NH}_{4}^{+}$and $\mathrm{NO}_{3}^{-}$in wastewater decreased from $26.0 \pm 4.0 \mathrm{mg} / \mathrm{L}$ to $2.5 \pm 0.5 \mathrm{mg} / \mathrm{L}$ and from $5.0 \pm 1.0 \mathrm{mg} / \mathrm{L}$ to 3.5 $\pm 0.5 \mathrm{mg} / \mathrm{L}$, respectively (Figure $4 \mathrm{a}$ ). $90 \%$ of the $\mathrm{NH}_{4}^{+}-\mathrm{N}$ and $30 \%$ of the $\mathrm{NO}_{3}^{-}-\mathrm{N}$ were removed from the wastewater. The nitrogen in wastewater existed in the form of organic nitrogen, $\mathrm{NH}_{4}^{+}-\mathrm{N}$ and $\mathrm{NO}_{3}^{-}-\mathrm{N}$. In the current study, the removal of odd nitrogen in wastewater relied on the assimilation of these compounds by water spinach in hydroponic systems. Firstly, $\mathrm{NH}_{4}^{+}$was converted to $\mathrm{NO}_{3}^{-}$and a portion of $\mathrm{NO}_{3}^{-}$would then be denitrificated to $\mathrm{N} 2$ by microorganisms. Another $\mathrm{NO}_{3}^{-}$portion was absorbed by water spinach via roots for growing. However, which process contributed more to the $\mathrm{NO}_{3}^{-}$removal was not clarified. In other words, $\mathrm{NO}_{3}^{-}$could be assimilated by plants or sent back to the atmosphere by the effect of denitrifying microorganisms (Xu et al., 1999).

\subsubsection{Phosphorus removal}

Phosphorus is the essential nutrient for plant growth. It can be assimilated by plants and be converted into various kinds of organic matter of plants (Gu et al., 2008). Water spinach, therefore, could assimilate $\mathrm{PO}_{4}^{3-}$ in wastewater and make a reduction from $8.5 \pm 1.5 \mathrm{mg} / \mathrm{L}$ to $1.2 \pm 0.2$ $\mathrm{mg} / \mathrm{L}$. Eighty six percent of $\mathrm{PO}_{4}^{3-}$ were removed from the wastewater.

\subsection{Control system}

On one hand, after HRT we observed moss stricking on the inner surface of pipes in the control system. On the other hand, SS created a visible layer of sediment on the inner surface. Moreover, activities of microorganisms could also break organic matters down in wastewater. Consequently, $\mathrm{SS}, \mathrm{BOD}_{5}$ and $\mathrm{COD}$ decreased (Figure $4 \mathrm{~b}$ ). Level of $\mathrm{pH}$ declined from 7.3 to 6.5 . That was probably because $\mathrm{NH}_{4}^{+}$was nitrificated to $\mathrm{NO}_{3}^{-}$as evidenced by decreasing $\mathrm{NH}_{4}^{+}$and increasing $\mathrm{NO}_{3}^{-}$concentrations at the end of the experiment.

\subsection{Suggested household hydroponic system}

A family with 4 people release approximately $400 \mathrm{~L}$ of wastewater a day (MONRE, 2016). A tank of $1600 \mathrm{~L}$ is needed to store wastewater in 4 days. According to the design in this study, 240 $\mathrm{m}$ of $\Phi 14-\mathrm{mm}$ uPVC pipe are enough to treat the total amount of wastewater in 4 days. Pipes can be arranged as in Figure 1 or in tower shapes to save space. Total pipe investment costs VND $18,163,200$. 


\section{Conclusions}

The averaged influent contained proximately $220.5 \mathrm{mg} / \mathrm{L}$ chemical oxygen demand (COD), $76.0 \mathrm{mg} / \mathrm{L}$ biological oxygen demand (BOD5), $32.5 \mathrm{mg} / \mathrm{L}$ suspended solids (SS), $26 \mathrm{mg} / \mathrm{L}$ $\mathrm{NH} 4+, 5.0 \mathrm{mg} / \mathrm{L} \mathrm{NO}_{3}^{-}$, and $8.5 \mathrm{PO}_{4}^{3-}$ at $\mathrm{pH} 7.3$. The designed system consisting of 10 plants of 15 day-old water spinach pre-planted in baked clay in each cup was capable of treating $30 \mathrm{~L}$ of domestic wastewater meeting the current municipal wastewater discharge standards in Vietnam (column A standards of QCVN 14:2008/BTNMT) after 4 days of wastewater retention time. If operated under conditions of the above parameters, the pilot-plant hydroponic system can achieve the removal of $74 \% \mathrm{COD}, 82 \% \mathrm{BOD}_{5}, 64 \% \mathrm{SS}$, $90 \% \mathrm{NH}_{4}^{+}, 30 \% \mathrm{NO}_{3}^{-}$and $86 \% \mathrm{PO}_{4}^{3-}$. The result of this study has provided an applicable domestic wastewater treatment system eco-friendly and suitable for small and medium household areas.

\section{References}

Dai, X., Guo, Y., Qian, H., Hu, W., \& Chen, W. (2012). The purification effect of three vegetables and different cultivation on aquaculture water from shrimp pond. Journal of Shanghai Ocean University 21(5), 777-783.

Gu, G. P., Zhou, L. Y., \& Wang, S. (2008). Primary Study on the Removal Efficiency of Nitrogen and Phosphorus of Eutrophic Water Body by Planted Float Ipomoea Aquatica Forsk. Auhui Agricultural Science Bulletin 14(19), 134-137.

Hoang, H. V., \& Tran, H. D. (2014). Drainage (II): Wastewater treatment. Science and Technology Publishers, Vietnam, 359-367.
Li, W., \& Li, Z. (2009). In situ nutrient removal from aquaculture wastewater by aquatic vegetable Ipomoea aquatica on floating beds. Water Science Technology 59(10), 1937-1943.

Luong, P. D. (2011). Wastewater treatment technology using biological methods. Vietnam: Education Publishers.

MONRE (Ministry of Natural Resources and Environment of Vietnam). (2016). The National Environmental Situation Report, 52-54.

Patnaik, S. (1976). Autecology of Impomoea aquatica Forsk. Journal of Inland Fisheries Society of India 8, 77-82.

Kanabkaew, T., \& Puetpaiboon, U. (2004). Aquatic plants for domestic wastewater treatment: Lotus (Nelumbo nucifera) and Hydrilla (Hydrillaverticillata) systems. Songklanakarin Journal Science Technology 26(5), 749-756.

Paul, J., \& Cay, B. (1990). Home Hydroponics. New York, USA: Crown Publishers.

VEA (Vietnam Environment Administration). (2010). Wastewater treatment by Buffalo Spinach and Hyacinth. Retrieved February 15, 2018, from http://vea.gov.vn/vn/quanlymt/Quanlychatthaicaith ien/caithienmt/Pages/Xulynuocthaibangraungovaluc binh.aspx.

Vymazal, J., \& Kropfelova, L. (2009). Removal of organics in constructed wetlands with horizontal subsurface flow: a review of the field experience. Science Total Environment 407(13), 3911.

Xu, H., Chen, H. Z., Xiong, Q. Q., \& Wang, B. Z. (1999). Studies on the Efficiencies and Mechanisms of $\mathrm{N}$ and $\mathrm{P}$ Removal in Macrohydrophyte Ponds. Journal of Harbin University of Civil Engineering and Architecture 32(4), 33-47. 